\title{
Pathological Study on the Role of Thymoquinone in Experimentally Induced Acute Lung
} Injury in Rats

\author{
Naif A. Al-Gabri ${ }^{1,2^{*}}$, Abdel-Moneim Ali ${ }^{1}$, El-Sayed AL-Attar ${ }^{1}$ and Mohammed Hamed ${ }^{1}$ \\ ${ }^{1}$ Pathology Department, Faculty of Veterinary Medicine, Zagazig University, 44511, Egypt \\ ${ }^{2}$ Veterinary Medicine Department, Faculty of Agriculture and Veterinary Medicine, Thamar \\ University, Dhamar, Yemen
}

Article History: Received: 21/4/2017 Received in revised form: 20/8/2017 Accepted: 5/9/2017

\begin{abstract}
Acute lung injury (ALI) is a major cause of morbidity and mortality in humans and animals. In traditional and modern medicines, Nigella sativa extract, thymoquinone (TQ) has several benefits. Here, we examined the counter effects of TQ in ALI induced by Lipopolysaccharide (LPS). Tissue sections and serum samples were collected from the following groups of rats: i) none treated control, ii) TQ only, iii) intratracheally (I.T) installed with LPS $200 \mu \mathrm{g} / \mathrm{rat}$ once, iv) TQ protected received intraperitoneally (I.P) $1 \mathrm{mg} / \mathrm{rat}$ for one week. Samples were subjected to histopathology, immunohistochemistry, ELISA and electron microscopy. TQ-treated rats revealed reduction in peribronchial, perivascular and interstitial inflammatory edema, thickening of interalveolar septa, inflammatory exudates in the lumens of airways and alveoli, hypertrophied smooth muscles of pulmonary blood vessels and airways and hyperplasia of bronchial associated lymphoid tissue (BALT). Electron microscopy revealed highly activated pneumocyte with vacuolated cytoplasm in TQ-treated group. Immunomodulators, IL $1_{\beta}$ and $\mathrm{TNF} \alpha$ showed lower levels in TQ-treated group. Meanwhile, NF- $\kappa \mathrm{B}$ was absent according to immunohistochemistry. It could be concluded that TQ restores lung architecture and reduces inflammatory Immunomodulators in ALI.
\end{abstract}

Keywords: Lipopolysaccharide, Thymoquinone, Acute lung injury, Rat

\section{Introduction}

Acute lung injury (ALI) is a clinical syndrome that involves disruptions of the gas exchange apparatus, therefore, it is considered as a severe complication often observed in intensive care units. Gram negative bacterial endotoxin lipopolysaccharides (LPS) administration has been used as an animal model of ALI and plays a main important role in the development of ALI. It could lead to mortality rates between 25 and $40 \%$ in the United States [1]. Many experimental protocols applied to achieve LPS-induced ALI via intratracheal [2,3], intranasal [4], atomized inhalation [5] or intraperitoneal route [6] were reported. The lesion was indicated by a notable inflammatory cells infiltration, interstitial and intra-alveolar edema, thickening of the alveolar septa and airways epithelium, hyaline membrane formation and some collapse in alveoli. ALI induced by LPS showed significant increase in the expression of proinflammatory cytokines TNF $\alpha$, IL- $1_{\beta}$ IL-6, IL8 [6-8], NF- $\kappa \mathrm{B}[9,10]$, reactive oxygen species
(ROS), nitric oxide (NO) and prostaglandin E2 (PGE2) [8]. These inflammatory mediators initiate and amplify the inflammatory response which results in the development of lung injury. Tang et al. [3] noted that, the I.T instillation of LPS caused pulmonary edema, microvascular protein leakage and cell damage. Moreover, Liu et al. [11] mentioned that the ALI is initially characterized by disruption of the interface between capillary/alveoli resulting in leakage of edema fluid into the interstitial and alveolar space, followed by an extensive release of proinflammatory cytokines, chemokines and infiltrations of neutrophil. These events cause reduced gas exchange and systemic inflammation with multi-organs failure. Ultrastructure changes in mice after LPS instillation was followed by severe injury of alveolar epithelium, swollen and fragmented type I and II cells (lamellar bodies in the alveolar space), intact endothelium of capillaries, hyaline membrane formation and neutrophil apoptosis [12]. Yuan et al. [13]

*Corresponding author email: (naifaljabry@yahoo.com), Pathology Department, Faculty of Veterinary 228 Medicine, Zagazig University, 44511, Egypt. 
noticed that the LPS-induced alterations in ultrastructures of endothelial cell (increase in the gap of intercellular junctions) which were abated by treatment with Ginsenoside in a rat.

Prophylactic and treatments attampts were applied to ameliorate the ALI induced by LPS through suppression of proinflammatory cytokines after treatment by acanthotic acid [4], andrographolide sulphate [5], mangolol [2], ginger extract or zingerone [14] and TQ $[6,15-17]$. TQ is a natural product with main constituents of the volatile oil from Nigella sativa seeds which exhibits anti-inflammatory and anticancer activities [18]. TQ had been proved to be effective in the treatment of many respiratory manifestations [9,15,19-23]. El Gazzar et al. [15] suggested that TQ attenuates the inflammatory response in LPS-stimulated mast cells by modulating nuclear transactivation of NF- $\kappa \mathrm{B}$ and TNF $\alpha$ production. Jafri et al. [10] reported inhibition of LPS induced $\mathrm{NF}_{\mathrm{k}}-\mathrm{B}$ by prior treatment with TQ in mice. This study aimed to evaluate the effectiveness of TQ on ALI induced by LPS via evaluation of histopatholoical, ultrastructure and histochemical changes in lung tissue beside proinflammatory cytokines in serum.

\section{Material and Methods}

\section{Materials}

Thymoquinone (2-isopropyl-5-methyl-1, 4benzoquinone), available in a yellow crystalline form was purchased from Sigma (St. Louis, Mo, USA). The dose of TQ was 1 $\mathrm{mg} / 200 \mu \mathrm{L}$ normal saline per rat dissolved in DMSO after I.P injection according to El Gazzar et al. [15]. Escherichia coli O55: B5 LPS was purchased from Sigma. LPS (I.T) installed by a dose of $200 \mu \mathrm{g} / \mathrm{rat}$ dissolved in $200 \mu \mathrm{L}$ normal saline according to Hou et al. [7]. Ketamine, xylazine and other chemicals were purchased from Kahira Pharmaceuticals \& Chemical Industries Company (4 AbdelHamid Eldeeb St. Victoria SQ. Shoubra. Cairo Egypt). IL1 $1_{\beta}$ and TNF $\alpha$ ELISA kit were purchased from Abcam ${ }^{\circledR}$ (332 Cambridge Science Park Milton Road Cambridge, Cambridge Shire UK). Immunohistochemistry primary antibody Rabbit polyclonal IgG to rat $\mathrm{NF}-\kappa \mathrm{B}$ was purchased from sigma.

\section{Animals}

Forty male healthy albino rats weighing $150 \pm 50 \mathrm{~g}$ were used in this study. Animals were obtained from the animal house of the Faculty of Veterinary Medicine, Zagazig University. They were housed for one week before the experiment for acclimatization. They were fed with a standard pellet ration (El-Nasr Chemical Company, Cairo, Egypt) and get free accesses to water ad libitum. All animals were managed according to the recommendations of the Committee of Animal Welfare and Research Ethics, Faculty of Veterinary Medicine, Zagazig University, Egypt.

\section{Experimental design}

Rats were divided into equal four experimental groups $(\mathrm{N}=10$, each). The first group was considered non-treated control group without any treatment. The second group was I.P injected by TQ $1 \mathrm{mg} / \mathrm{rat}$ dissolved in DMSO daily for one week. The third group was I.T installed by LPS 200 $\mu \mathrm{g} / \mathrm{rat}$ dissolved in $200 \mu \mathrm{L}$ normal saline once after anesthetized. Finally, the fourth group was I.P injected by TQ daily for one week before and through the LPS installation. Animals were sacrificed after twelve and twenty-four hours from LPS installation. Serum samples and lung tissue specimens were collected from all forty sacrificed rats to study the different parameters.

\section{LPS-induced acute lung injury}

LPS-induced ALI was applied after a modified manner similar to previous reports of Rivera et al. [24]. Briefly, rats were anesthetized with ketamine-xylazine at a dose $80 \mathrm{mg} / \mathrm{kg}$ and $12 \mathrm{mg} / \mathrm{kg}$, respectively, by I.P injection. The rat was fixed on (our designed) glass board at an angle of $70^{\circ}$ in a supine position. A volume of $200 \mu \mathrm{L}$ normal saline or normal saline containing $200 \mu \mathrm{g}$ LPS was installed into the rat trachea by use of a 3gauge intravenous needle. After I.T instillation, the rats were placed in a vertical position and rotated for $0.5-1 \mathrm{~min}$ to distribute the instillation evenly within the lungs. 
Table 1: Lesion scoring according to different criteria

\begin{tabular}{|c|c|c|c|c|c|}
\hline & \multirow{2}{*}{ Criteria } & \multicolumn{4}{|c|}{ Experiment Groups } \\
\hline & & CON & TQ & LPS & TQ-LPS \\
\hline Airways & $\begin{array}{l}\text { Proliferated epithelium and goblet } \\
\text { cells metaplasia }\end{array}$ & - & - & +++ & + \\
\hline \multirow[t]{3}{*}{ (bronchus, bronchioles) } & Injury of smooth muscles & - & - & +++ & + \\
\hline & $\begin{array}{l}\text { Hyperplasia of bronchial associated } \\
\text { lymphoid tissues (BALT) }\end{array}$ & - & - & +++ & + \\
\hline & Injury of endothelium & - & - & +++ & + \\
\hline \multirow[t]{2}{*}{ Pulmonary blood vessels } & Hyperplasia of smooth muscles & - & + & +++ & + \\
\hline & Perivascular edema & - & + & +++ & + \\
\hline \multirow{5}{*}{$\begin{array}{l}\text { Alveolar tissue } \\
\text { (alveoli and air-blood parries) }\end{array}$} & $\begin{array}{l}\text { Hypertrophied and hyperplasia of } \\
\text { pneumocytes I \& II }\end{array}$ & - & - & +++ & + \\
\hline & Thickening of alveoli septa & - & + & +++ & + \\
\hline & Atelectasis & - & + & +++ & + \\
\hline & Inflammatory cells Infiltration & - & + & +++ & + \\
\hline & Emphysema & - & + & +++ & + \\
\hline
\end{tabular}

- = Normal, += Mild, ++= Moderate, +++= Severe.

\section{Histopathological techniques}

Rats were sacrificed after anesthetized on $12 \mathrm{~h}$ and $24 \mathrm{~h}$ post LPS installation. Pathological specimens (lungs) were collected and put in $10 \%$ neutral buffered formalin fixation. Fixed tissues were processed routinely by the paraffin embedding technique [25]. Preparations were evaluated by a light microscopy by using lesions score. Lesion scoring was represented by $-=$ Normal, $+=$ Mild, $++=$ Moderate and $+++=$ Severe according to Robert [26] and Gibson-Corley et al. [27].

\section{Electron microscopic techniques}

The lung specimens were rapidly sectioned in thin sections and fixed directly in $2.5 \%$ glutaraldehyde at $\mathrm{pH} 7.2$ (at ambient temperature) for $4 \mathrm{~h}$ and in $1.33 \%$ osmium tetroxide buffered overnight at 4 degrees (refrigerator) and embedded in epoxy resin (plastic media). Ultra-thin sections were obtained by ultra-microtome according to Cheville and Stasko [28]. They were evaluated for detection of lesions before the tissue upload on the grid and stained by uranium and lead citrate. Finally, the ultra-sections were evaluated by transmission electron microscopy (JEOL JEM-1230).

\section{Immunohistochemical detection of activated $N F-\kappa B$}

Paraffin-embedded tissue sections of $3 \mu$ thickness were deparaffinized in xylene and then rehydrated in descending graded alcohol. The sections were blocked with $5 \%$ bovine serum albumin (BSA) in Tris-buffered saline (TBS) for $2 \mathrm{~h}$. The sections were immunostained with primary antibody (Rabbit polyclonal $\mathrm{IgG}$ to rat $\mathrm{NF}-\kappa \mathrm{B})$ at a concentration of $1 \mathrm{~g} / \mathrm{mL}$ containing $5 \%$ BSA in TBS and incubated overnight at $4^{\circ} \mathrm{C}$. Post incubation, the slides were washed by TBS, goat anti-rabbit secondary antibodies were added to the slides and then incubated. Sections were washed by TBS then incubated for $5-10 \mathrm{~min}$ in $0.02 \%$ diaminobenzidine containing $0.01 \%$ hydrogen peroxide. Counter staining was applied by using hematoxylin, the slides were visualized under a light microscope. 


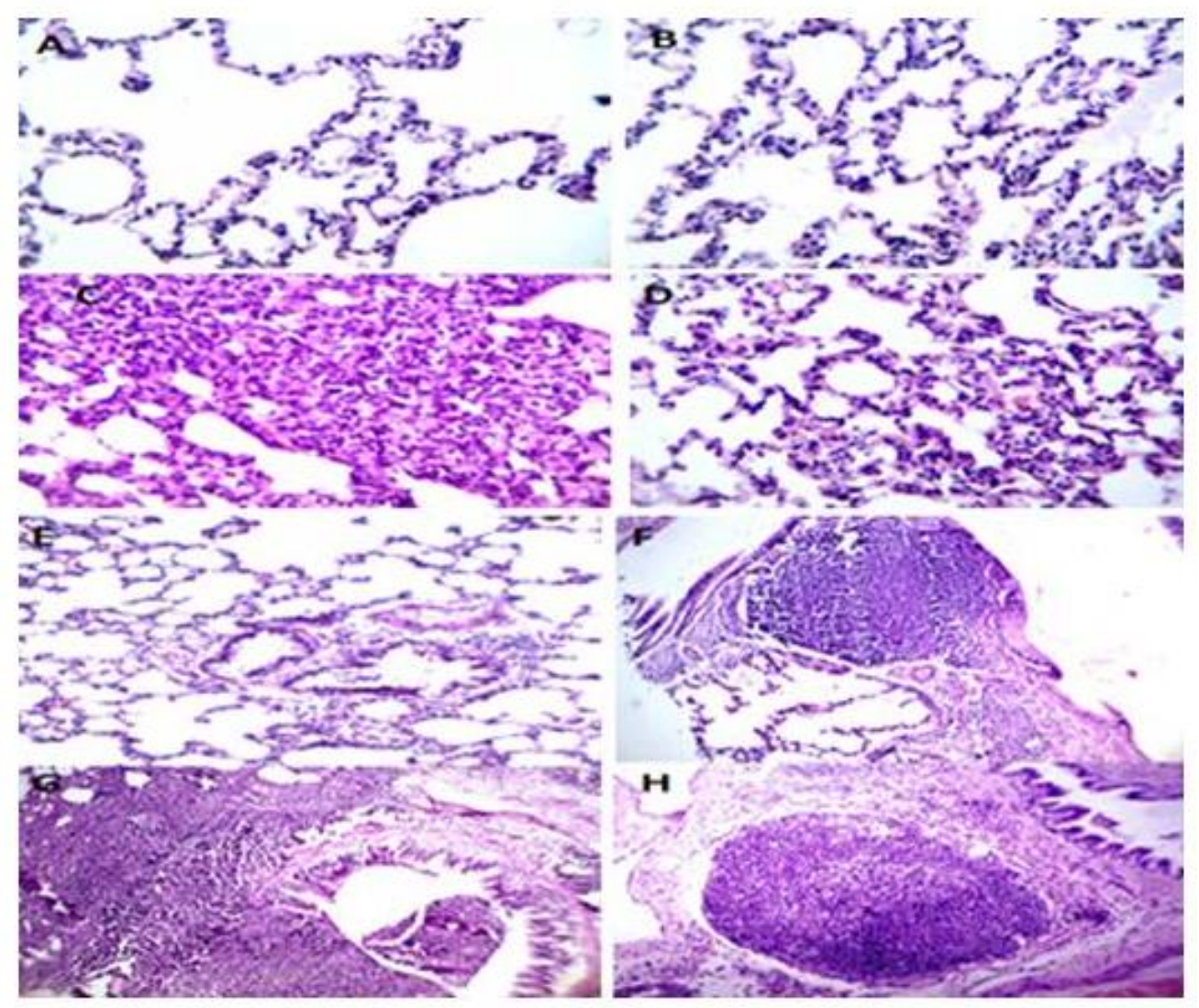

Figure 1: Photomicrograph of rat lung 24 hours post LPS installation showing alveolar normal septa in group A (Control) and group B (TQ only). Thickening of septa with focal replacement by edema and inflammatory cells infiltrations were noticed in group $C$ (LPS) and restore of pulmonary architecture were common in group D (TQ+LPS). H\&E X 400. Bronchial tree appeared normal in group E (Control) and mild hyperplastic of BALT in group F (TQ only). Severe thickening of bronchial wall with exudate are common in group G (LPS). Meanwhile, mild hyperplasia of BALT and bronchial epithelial were seen in group H (TQ+LPS) H\&E $\mathrm{X} 200$.

\section{Enzyme-Linked Immunosorbent Assay (ELISA)}

Sera levels of $\operatorname{IL}_{\beta}$ and TNF $\alpha$ were measured by using ELISA kit, according to Chehl et al. [29]. The sensitivity of the assay was $5.1 \mathrm{pg} / \mathrm{mL}$. The samples were examined in duplicate and the experiment was repeated at least three times.

\section{Results}

\section{Histopathological changes}

Rats in group i (control) and group ii (TQ only) revealed alveolar septa and lung tissue was within the normal morphohistological structures. Meanwhile, rats instilled I.T with $200 \mu \mathrm{g}$ LPS and sacrificed 12 and $24 \mathrm{~h}$ post installation revealed variable degrees of lesions represented by perivascular, peribronchial and intra-alveolar serous or serofibrinous edema admixed with inflammatory cells mainly lymphocytes, granulocytes, plasma cells and few macrophages. Thickening of alveolar septa was noticed due to congestion and hemorrhage and inflammatory cell infiltrations. Hypertrophy and hyperplasia of pneumocytes type I and type II were detected. The wall of alveoli showed hyalinized and eosinophilic membrane with partial destruction of their lining epithelium and intraluminal infiltration of leukocytes and erythrocytes. Some alveoli showed focal hypertrophic or hyperplastic changes in pneumonia type I and type II. Focal compensatory alveolar emphysema was also seen. Rats in group four which treated with TQ (I.P) prior LPS (I.T), returned back to the normal alveolar septal morphohistological structures, however, mild thickening of alveolar septa by congestion and infiltration of dead and living neutrophils were seen in some cases (Figure 1: A,B,C,D). 

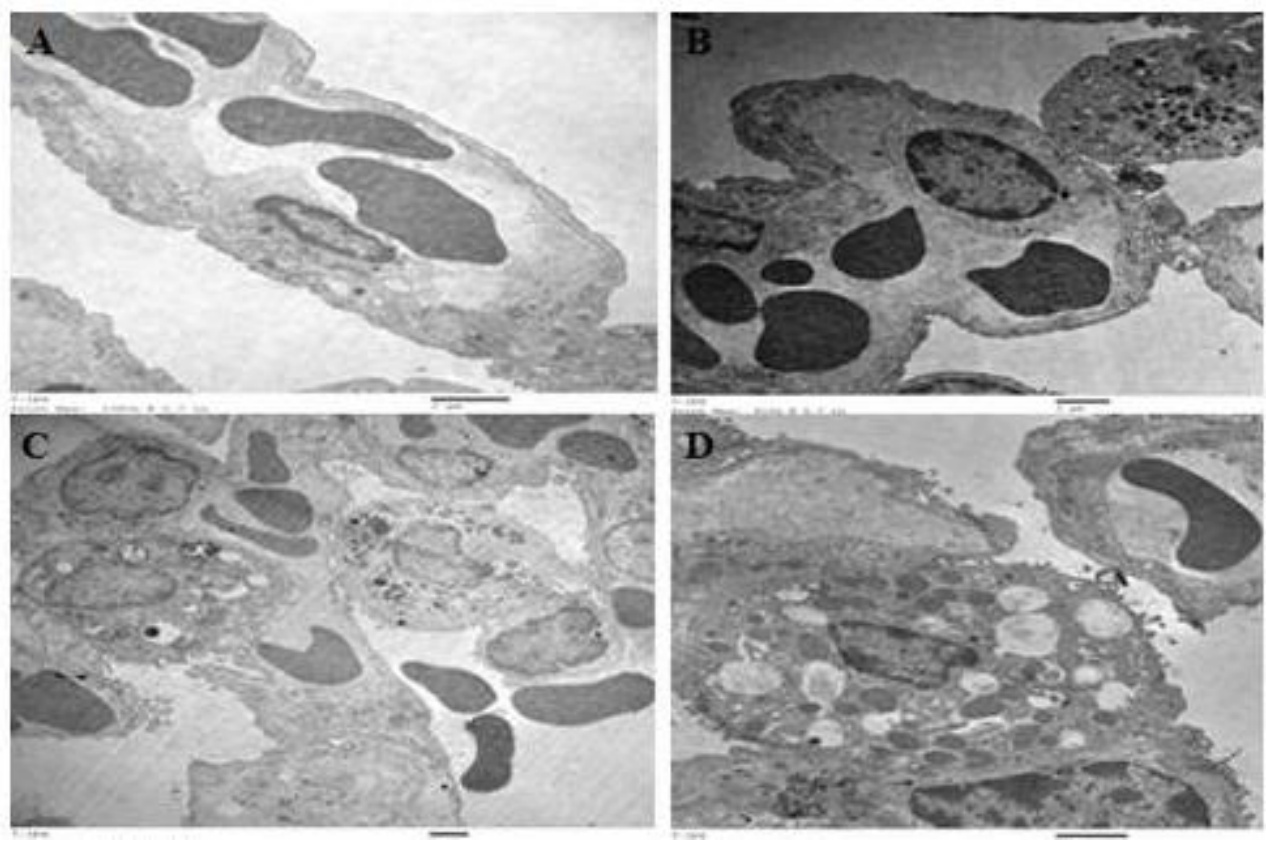

Figure 2: A: Electron micrograph of the ultrastructure of capillaries which appeared blood-air barrier (intact capillary wall) within normal morphology seen in group A (control). Dilated capillaries contain active monocyte and pneumocytes contain dense bodies following by excess surfactant in intercellular gaps were seen in group B (TQ only). Exude pneumocytes contain lamellar bodies and erythrocytes with the alveolar lumen group $C$ (LPS). Highly activated pneumocyte with vacuolated cytoplasm was seen in group D (TQ+LPS). Uranium and lead citrate stain. Magnification A) X 2000, B) X 1500, C) X 1000, D) X 2000.

Bronchial tree in group i (control) appeared within the normal histomorphological architectures. Mild hyperplastic of BALT was observed in group ii (TQ only). Rats instilled LPS revealed acute bronchitis, and bronchiolitis. Their luminae contained few amount of mucus with desquamated epithelium and inflammatory cells. Proliferated epithelia and goblet cells metaplasia were detected with or without intraepithelial inflammatory cells, together with edematous and hypertrophied vascular smooth muscles. Bronchial associated lymphoid tissues (BALT) were hyperplastic and had reactive germinal centers. Rats in group four (TQ+LPS) revealed enhanced curative effects of TQ as represented by mild to moderate acute bronchitis include bronchial epithelium desquamation and infiltration of the bronchial wall by inflammatory cells. Mild hyperplasia of BALT could be seen. Some of the examined sections of the same rats appeared as apparently healthy alveolar and bronchial tissue (Figure 1: E,F,G,H). Other blood vessels revealed vascular endothelial hyperplasia (endotheliosis), subintimal and medial hyalinization and vacuolation in group iii (LPS). Semi-quantitative analyses of lung injury scores for the experimental groups were demonstrated (Table 1).

\section{Ultra-structure changes}

Electron microscopic examination of LPS installated rats revealed many ultrastructure changes, mainly thickening of air-blood barriers by activated pneumocytes type II which contained a large amount of lamellar bodies (surfactant). While, some alveolar luminae contained exuded pneumocytes, inflammatory cells and erythrocytes. TQ treated rats showed mild electron microscopically changes as represented by the presence of some lamellar bodies within activated pneumocytes type II and presences of interalveolar degenerated inflammatory cells (Figure 2).

\section{Immunohistochemical changes of NF-кB expression in lung tissue}

The concentration of NF-kB was determined by immune-histology. The control and TQ only groups were not stained, while, the TQ+LPS group has obviously decreased positivity rates than the LPS only group (Figure 3). 
Enzyme-Linked Immunosorbent Assay for serum levels of IL $1_{\beta}$ and TNFa

The levels of IL $1_{\beta}$ and TNF $\alpha$ measured by ELISA technique showed normal levels in rats subjected to TQ only and control $(79.05,82.7$ and 175.6, $173 \mathrm{pg} / \mathrm{mL}$ ) respectively. Rats received LPS had high levels of $\mathrm{IL}_{\beta}$ and $\mathrm{TNF} \alpha(182.5$ and $231.5 \mathrm{pg} / \mathrm{mL})$, respectively. Meanwhile, rats treated with TQ+LPS revealed a significant reduction in levels of $\mathrm{IL} 1_{\beta}$ and $\mathrm{TNF} \alpha(162.4$ and $192 \mathrm{pg} / \mathrm{mL})$, respectively (Figure 4).

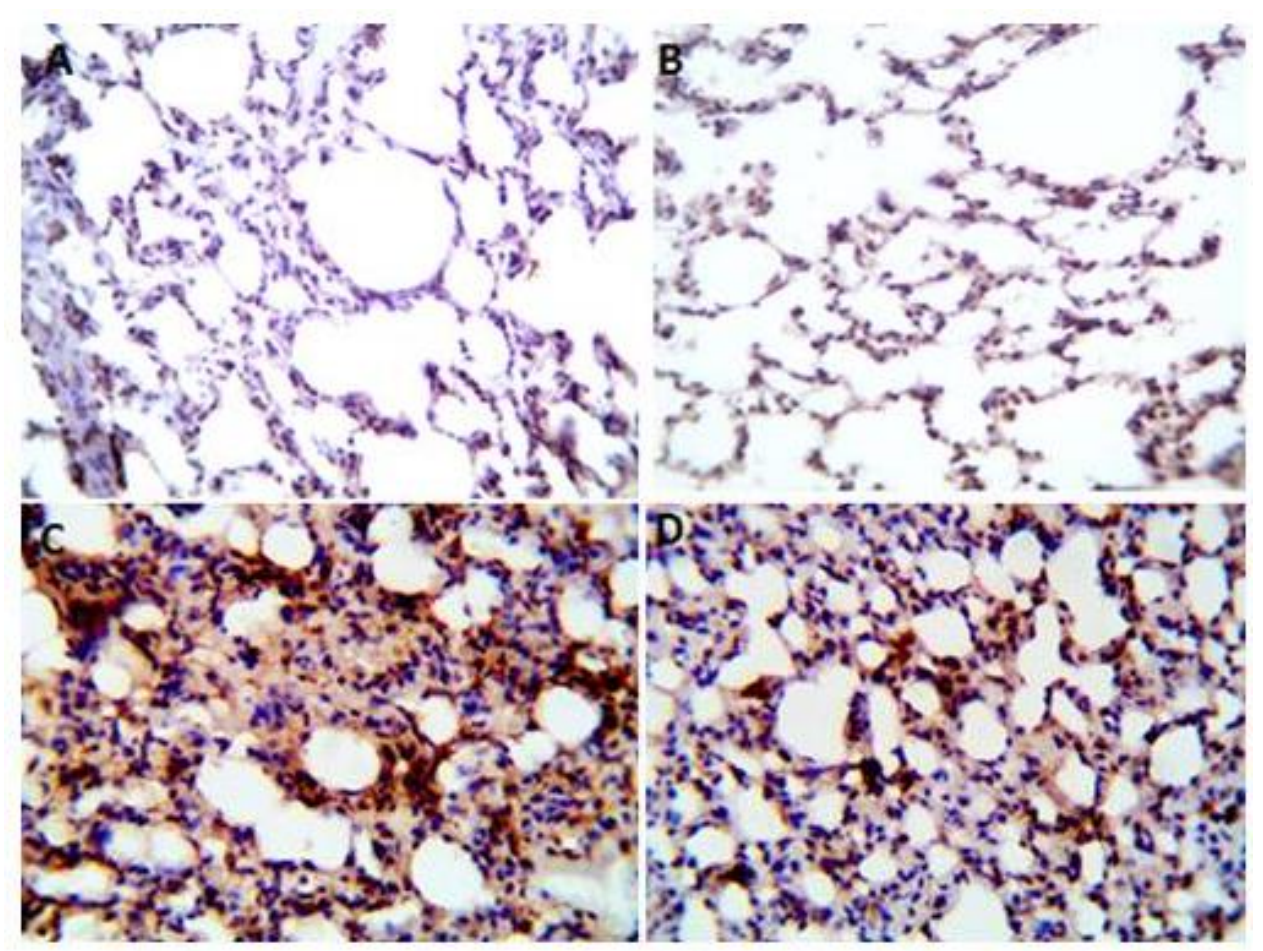

Figure 3: Photomicrograph lung of rat (immunohistochemistry of NF-kB) showing normal expression in both groups A (Control) and B (TQ only). Intense expression of NF-kB was seen in group C (LPS). Mildly immune stain reactivity of NF-kB was noticed in group D (TQ+LPS) X400.

\section{Discussion}

TQ has antioxidant and anti-inflammatory activities both in vitro and in vivo since its extraction from Nigella sativa in the 1960s [30]. In the present study, we used rats as an experimental model of LPS-induced acute lung injury to investigate the potential antiinflammatory effect of TQ. In addition, the underlying mechanisms of TQ were assessed by studying its effect on different parameters mainly pulmonary lesions, ultra-structural changes and proinflammatory cytokines $\mathrm{IL}_{\beta}$, $\mathrm{TNF} \alpha$ as well as the expression of NF- $\mathrm{BB}$ in activated form. This investigation declared that LPS could induce a significant lung injury represented by peribronchial, periarteriolar inflammatory edema and thickening of interalveolar wall, hypertrophied and hyperplastic pneumocytes. The vascular tunica had a different degree of angiopathy mainly endotheliosis and hypertrophy of vascular smooth muscle was common. These results coordinate with the results reported by Tang et al. [3] and Liu et al. [11].

The airways revealed mucous exudates within the lumen admixed by inflammatory cells and desquamated epithelial sheets. Moreover, bronchiolar epithelium showed proliferation with invasiveness by inflammatory cells. Hypertrophied and hyperplasia of BALT were pronounced. These findings were consistent with previous reports [31,32]. Furthermore, emphysema due to the presence of mucus in bronchial lumina was detected, similar finding was also reported $[33,34]$. 

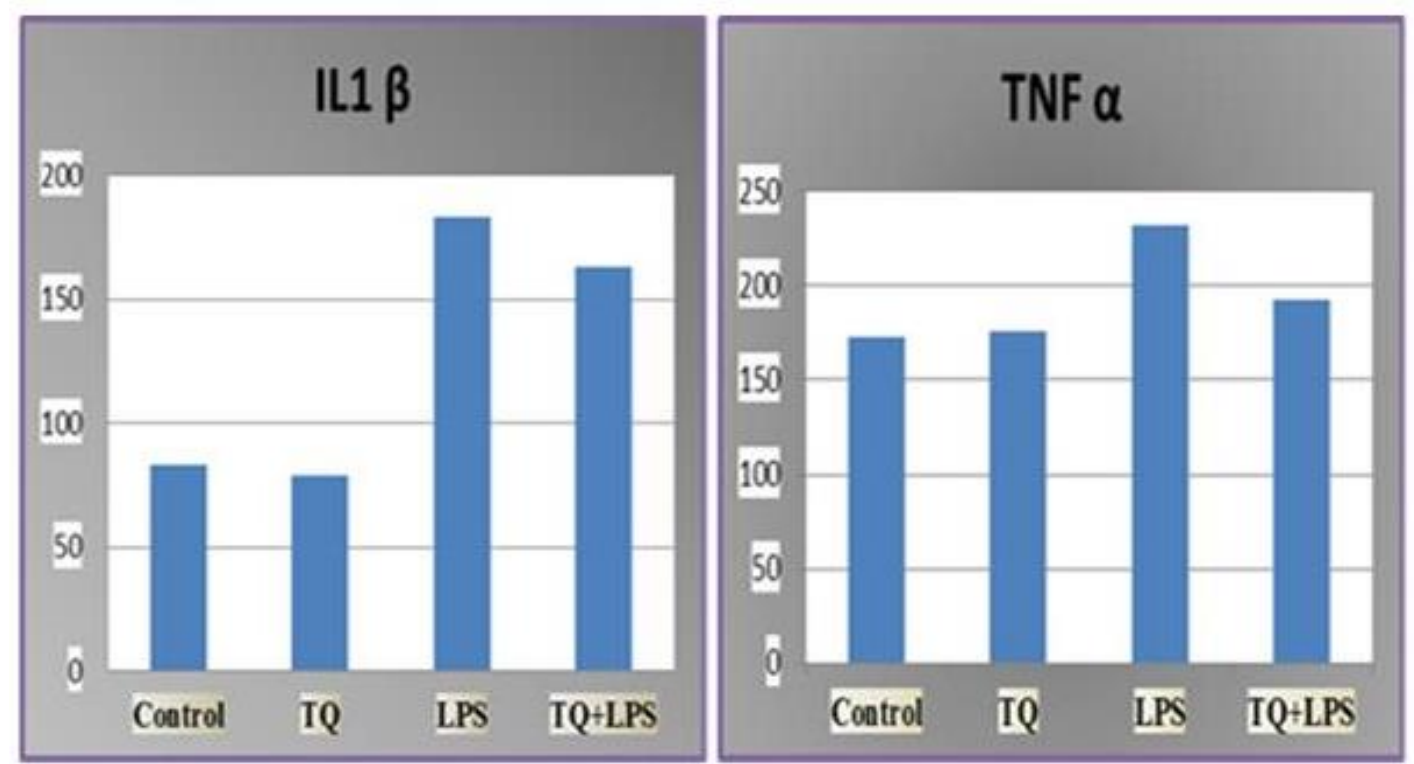

Figure 4: Graphs of serum levels of $\mathrm{IL1}_{\beta}$ and $\mathrm{TNF} \alpha(\mathrm{pg} / \mathrm{ml})$ in different experiment groups

Moreover, our results revealed a significant increase in sera levels of both $\mathrm{IL} 1_{\beta}$ and TNF $\alpha$. However, NF- $\kappa \mathrm{B}$ showed intense reactivity in LPS significant as the previous report [16]. Concurrent treatment of rats with TQ significantly counteracted the inflammatory effect of LPS and moderated all the injury markers up to the normal levels $[6,15$, 17,35,36]. At the same context, expression of the activated NF-kB revealed a mild degree in rats treated with $\mathrm{TQ}$, a finding consistent with the existence of constitutive $\mathrm{NF}-\kappa \mathrm{B}$ levels in alveolar macrophages. Recent studies on the anticancer activity of TQ noticed inhibition of $\mathrm{NF}-\kappa \mathrm{B}$ with regression of epithelial mammary tumor [37,38].

One of the widely mechanisms for LPSinduced ALI declared that LPS is one of the important pathogen-associated molecular patterns (PAMP) and thereby a powerful stimulator of the host inflammatory reaction. LPS elicit this response by binding to the receptor on the surface of cells known as 'pattern recognition receptors' or PRRs which composed of at least three distinct proteins: CD14, Toll-like receptor-4 (TLR4), and Lymphocyte antigen 96. LPS inflammation followed by many inflammatory mediators, including tumor necrosis factor TNF- $\alpha$ and $\mathrm{IL}_{\beta}$ which play an important role in the cascade of inflammatory events [39].

\section{Conclusion}

It is concluded that TQ has ameliorative effects on the ALI via remodeling of the proinflammatory cytokines.

\section{Conflict of interest}

The authors declare no conflict of interest.

\section{References}

[1] Matthay, M.A.; Ware, L.B. and Zimmerman, G.A. (2012): The acute respiratory distress syndrome. $\mathrm{J}$ Clin Invest, 122(8): 2731-2740.

[2] Lin, M.H.; Chen, M.C.; Chen, T.H.; Chang, H.Y. and Chou, T.C. (2015): Magnolol ameliorates lipopolysaccharideinduced acute lung injury in rats through PPAR- $\gamma$-dependent inhibition of NF-kB activation. Int Immunopharmacol, 28(1):270-278.

[3] Tang S.E.; Wu, C.P.; Wu, S.Y.; Peng, C.K.; Perng, W.C.; Kang, B.H.; Chu, S.J. and Huang, K.L. (2014): Stanniocalcin-1 ameliorates lipopolysaccharide-induced pulmonary oxidative stress, inflammation, and apoptosis in mice. Free Radic Biol Med, 71:321-331.

[4] Qiushi, W.; Guanghua, L. and Guangquan, X. (2015): Acanthoic acid ameliorates lipopolysaccharide-induced acute lung injury. Eur J Pharmacol, 750: 32-38. 
[5] Peng, S.; Hang, N.; Liu, W.; Guo, W.; Jiang, C.; Yang, X.; Xu, Q. and Sun, Y. (2016): Andrographolide sulfonate ameliorates lipopolysaccharide-induced acute lung injury in mic by downregulating MAPK and NF- $\mathrm{BB}$ pathways. Acta Pharm Sin B, 6(3):205-211

[6] Abd El Aziz, A.; El Sayed, N. and Mahran, L.G. (2011): Anti-asthmatic and Antiallergic effects of Thymoquinone on Airway-Induced Hypersensitivity in Experimental Animals. J App Pharm Sci, 1 (8): 109-117

[7] Hou S.; Ding, H., Lv, Q., Yin, X., Song, J., Landén, N.X., and Fan, H. (2014): Therapeutic Effect of Intravenous Infusion of Perfluorocarbon Emulsion on LPS-Induced Acute Lung Injury in Rats. Plos One, 9(1), e87826.

[8] Chen, Y.C.; Shen, S.C.; Lee, W.R.; Hou, W.C.; Yang, L.L.; Lee, T.J. (2001): Inhibition of nitric oxide synthase inhibitors and lipopolysaccharide induced inducible NOS and cyclooxygenase-2 gene expressions by rutin, quercetin, and quercetin pentaacetate in RAW 264.7 macrophages. J Cell Biochem, 82(4):537548.

[9] Liu, W.; Jiang, H.L.; Cai, L.L.; Yan, M.; Dong, S.J. and Mao, B. (2016): Tanreqing Injection Attenuates LipopolysaccharideInduced Airway Inflammation through MAPK/NF-kB Signaling Pathways in Rats Model. Evid Based Complement Alternat Med, Vo.2016, Article ID 5292346, 15 pages.

[10] Jafri, S.H.; Glass, J.; Shi, R.; Zhang, S.; Prince, M. and Kleiner-Hancock, $\mathrm{H}$. (2010): Thymoquinone and cisplatin as a therapeutic combination in lung cancer: In vitro and in vivo. $\mathrm{J}$ Exp Clin Cancer Res, 29(1):87.

[11] Liu, K.D. and Matthay, M.A. (2008): Advances in critical care for the nephrologist: acute lung injury/ARDS. Clin J Am Soc Nephrol, 3(2): 578-586.

[12] Kolomaznik, M.; Zila, I.; Kopincova, J.; Mokra, D. and Calkovska, A. (2014): Changes in Lung Surfactant Proteins in Rats With Lipopolysaccharide--Induced
Fever. Physiol. Res, 63 (Suppl. 4): S619S628.

[13] Yuan Qing, Yan-wen Jiang, Ting-ting Ma, Qiu-hong Fang and Lei Pan (2014): Attenuating effect of Ginsenoside Rb1 on LPS-induced lung injury in rats. Journal of Inflammation, 11:40.

[14] Hsiang, C.Y.; Cheng, H.M.; Lo, H.Y.; Li, C.C.; Chou, P. C.; Lee, Y.C. and Ho, T.Y. (2015): Ginger and Zingerone Ameliorate LPS-Induced Acute Systemic Inflammation in Mice, Assessed by Nuclear Factor- $\kappa$ B Bioluminescent Imaging. J Agric Food Chem, 63 (26): 6051-6058.

[15] El Gazzar, M.A.; El Mezayen, R.; Nicolls, M.R. and Dreskin, S.C. (2007): Thymoquinone attenuates proinflammatory responses in lipopolysaccharide-activated mast cells by modulating NF-kappaB nuclear transactivation. Biochim Biophys Acta, 1770(4): 556-564.

[16] Barnawi J.; Tran, H.B., Roscioli, E., Hodge, G., Jersmann, H., Haberberger, R., and Hodge, S. (2016): Pro-phagocytic Effects of Thymoquinone on Cigarette Smoke-exposed Macrophages Occur by Modulation of the Sphingosine-1phosphate Signalling System. J. of Chronic Obstructive Pulmonary Disease. 13(5): 653-661.

[17] Wang, Y.; Gao, H., Zhang, W., Zhang, W., \& Fang, L. (2015): Thymoquinone inhibits lipopolysaccharide-induced inflammatory mediators in BV2 microglial cells. International Immunopharmacology, 26(1): 169-173.

[18] Leong, X.F.; Rais Mustafa, M. and Jaarin, K. (2013): Nigella sativa and Its Protective Role in Oxidative Stress and Hypertension. Evid Based Complement Alternat Med, Volume 2013, Article ID 120732, 9 pages.

[19] Gado, A. and Yassen, A. (2012): Protective effect of thymoquinone and aminoguanidine against bleomycin induced lung damage: possible role of nitric oxide synthase. Internet $\mathbf{J}$ Toxicol, 8(2): 1-8. 
[20] Keyhanmanesh R.; Boskabady, M.H., Khamneh, S., and Doostar, Y. (2010): Effect of thymoquinone on the lung pathology and cytokine levels of ovalbumin-sensitized guinea pigs. Pharmacological reports, 62(5): 910-916.

[21] Kanter Mehmet (2010): Thymoquinone attenuates lung injury induced by chronic toluene exposure in rats. Toxicology and Industrial Health, 27(5): 387-395.

[22] Aljohani Z.M.; Alharbi, A.; Alsaedi, M., Alahmadi, A., Alahmadi, O., Alharbi, A.A. and Unit, P.C. (2015): Evaluation of the Potential Beneficial Effects of Thymoquinone Against Nicotine Induced Toxicity.Int J Pharm Clin Res, 7(6):395398

[23] Yurttaş, V., Şereflican, M., Erkoçoğlu, M., Dagli, M., Terzi, E.H., Frrat, T., and Seyhan, S. (2016): Comparison of Histopathological Effects of Thymoquinone and Local Nasal Corticosteroids in Allergic Rhinitis in a Rabbit Model. Journal for Oto-RhinoLaryngology, Head and Neck Surgery, 78(1):55-60.

[24] Rivera, B.; Miller, S. R.; Brown, E. M. and Price, R. E. (2005): A Novel Method for Endotracheal Intubation of Mice and Rats Used in Imaging Studies. Ame Ass Lab Anim Sci, 44, (2): 52-55.

[25] Suvarna SK, Layton C and Bancroft JD. (2012): Bancroft's Theory and Practice of Histological Techniques. 7th ed., Churchill Livingstone. Elsevier, England.

[26] Robert K. (2013): Multiparametric and semi quantitative scoring systems for the evaluation of mouse model histopathology. Veterinary Research, 9(1):123.

[27] Gibson-Corley K.N.; Olivier, A.K., \& Meyerholz, D.K. (2013): Principles for valid histopathologic scoring in research. Vet Pathol, 50(6):1007-1015.

[28] Cheville, N.F. and Stasko, J. (2014): Techniques in Electron Microscopy of Animal Tissue. Vet Pathol, 51 (1): 2841.
[29] Chehl, N.; Chipitsyna, G.; Gong, Q.; Yeo, C.J. and Arafat, H.A. (2009): Antiinflammatory effects of the Nigella sativa seed extract, thymoquinone, in pancreatic cancer cells. International Hepato-Pancreato-Biliary Association, 11(5): 373-381.

[30] Woo C.; Kumar A.; Sethi, G. and Tan K. (2012): Thymoquinone: potential cure for inflammatory disorders and cancer. Biochem Pharmacol, 83(4): 443-451.

[31] Van der Brugge-Gamelkoorn GJ, Plesch BE, Sminia $\mathrm{T}$ and Langevoort HL. (1985): Histological changes in rat bronchus-associated lymphoid tissue after administration of five different antigens. Respirations 48(1):29-36.

[32] Gregson RL, Davey MJ and Prentice DE (1979): The response of rat bronchusassociated lymphoid tissue to local antigenic challenge. J Exp Pathol, 60(5):471-482.

[33] Kohno M, Ishizaka A, Sawafuji M, Koh H, Hirayama Y, Ikeda E, Shiomi T, Ohashi A, Okada Y, Kobayashi K (2004):Hyperoxia-induced emphysematous changes in subacute phase of endotoxininduced lung injury in rats. American Journal of PhysiologyLung Cellular and Molecular Physiology, 287(1): L184-L190.

[34] Stolk J, Rudolphus A, Davies P, Osinga D, Dijkman JH, Agarwal L, Keenan KP, Fletcher D, Kramps JA (1992): Induction of emphysema and bronchial mucus cell hyperplasia by intratracheal instillation of lipopolysaccharide in the hamster. $\mathrm{J}$ Pathol. 167(3):349-356.

[35] Ammar, E.S.M., Gameil, N.M., Shawky, N.M. and Nader, M.A. (2011): Comparative evaluation of antiinflammatory properties of thymoquinone and curcumin using an asthmatic murine model. International Immunopharmacology, 11(2): 22322236.

[36] Hosseini M.; Zakeri, S., Khoshdast, S., Yousefian, F.T., Rastegar, M., Vafaee F.; Kahdouee S, Ghorbani F, Rakhshandeh H, and Kazemi S.A. (2012): The effects 
of Nigella sativa hydroalcoholic extract and thymoquinone on lipopolysaccharide induced depression like behavior in rats. J Pharm Bioallied Sci, 4(3): 219-225.

[37] Connelly L.; Barham W.; Onishko H.M.; Sherrill T.; Chodosh L.A.; Blackwell T.S.; Yull F.E., (2011): Inhibition of NFkappa $\mathrm{B}$ activity in mammary epithelium increases tumor latency and decreases tumor burden. Oncogene, 30(12): 14021412.
[38] Sethi G.; Ahn K.S. and Aggarwal B.B. (2008): Targeting nuclear factor-kappa B activation pathway by thymoquinone: role in suppression of antiapoptotic gene products and enhancement of apoptosis. Mol Cancer Res, 6(6):1059-1070.

[39] Raetz, C.R.H. and Whitfield, C. (2002): Lipopolysaccharide endotoxins. Annual Review of Biochemistry, 71(1): 635700 .

$$
\begin{aligned}
& \text { الملخص العربي } \\
& \text { دراسة باثولوجية عن دور الثيموكينون في اصابات الرئه الحاده المستحدثه تجريبيا في الفئران }
\end{aligned}
$$

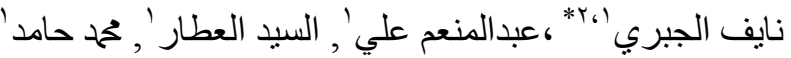

$$
\begin{aligned}
& \text { 'قسم الباتولوجي, كلية الطب البيطري, جامعه الزقازيق, مصر } \\
& \text { "َسم الطب البيطري, كليه الزراعه والطب لبيطري, جامعه ذمار, اليمن }
\end{aligned}
$$

إصابة الرئة الحادة (ALI) سبب رئيسي للوفيات والامر اضيه في البشر و الحيوانات. في الأدوية التقليدية و الحديثة

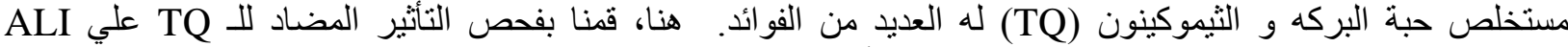

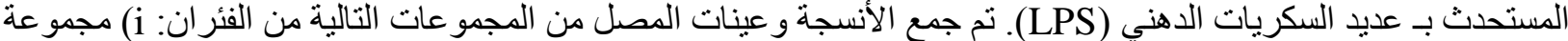

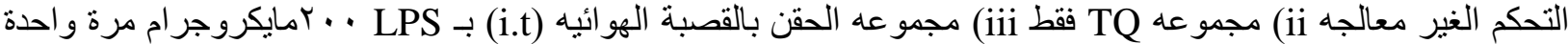

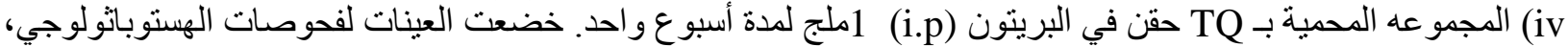
كيمياء الانسجه المناعيه، الاليزا و المجهر الإلكتروني. كشفت الفئران المعالجة بـ TQ تناقص الوذهة الونه الالتهابيه في محيط

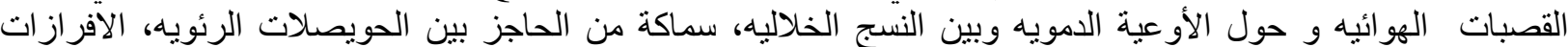
التهابات في تجويف الثعب الهوائية والحويصلات الهوائية و تضخم في العظلات الملساء لجدار الاوعيه الدمويه و القصبات

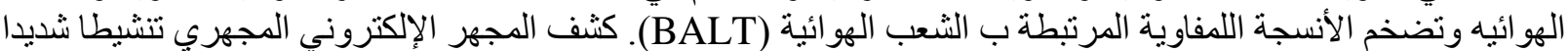

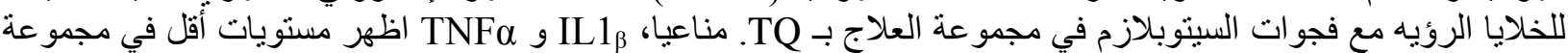

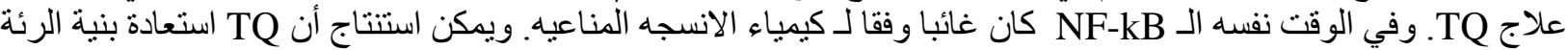
و الحد من مناعة التهابات في 